\title{
Tourism and economic growth: Does democracy matter?
}

\author{
Nikolaos Antonakakis* ${ }^{* \dagger} \quad$ Mina Dragouni ${ }^{\ddagger} \quad$ Bruno Eeckels ${ }^{\S} \quad$ George Filis
}

May 17, 2016

Tourism studies have shown a growing interest in the relationship between tourism and the economy, with relevant work exploring the causal direction of effects between a country's international tourism presence and its overall economic performance (see, Schubert et al., 2011; Chatziantoniou et al., 2013; Ivanov and Webster, 2013; Antonakakis et al., 2015, among others). The product of this enquiry is a mosaic of different, often opposing interpretations (e.g. tourismled growth against economy-driven tourism) that render this area of research inconclusive and still open to discussion.

In their majority, relevant studies focus on specific destinations. However, a cross-sectional analysis of the tourism-economy dynamics allows for a more in-depth and comparative examination of different states (Dritsakis, 2012). In addition, it is plausible to argue that the use of panel data can decrease endogeneity through the consideration of specific country effects, omitted variables, reverse causality and measurement error. In this respect, some papers (Seetanah, 2011; Chang et al., 2012) explore multiple countries classified on certain criteria, mostly geographic or economic. This study introduces another factor to the said enquiry that has so far been neglected, namely, the destinations' quality of political institutions (or political regime).

The political economy literature has long established the effects of institutional quality on the relationship between economic growth and economic resources (see, inter alia, Rodriguez and Sachs, 1999; Mehlum et al., 2006; Acemoglu et al., 2008). Thus, we postulate that political regime (as approximated by the level of democracy) in a particular country can influence the

\footnotetext{
${ }^{*}$ Webster Vienna University, Department of Business \& Management, Praterstrasse 23, 1020, Vienna, Austria.

${ }^{\dagger}$ University of Portsmouth, Economics and Finance Subject Group, Portsmouth Business School, Portland Street, Portsmouth, PO1 3DE, United Kingdom.

${ }^{\ddagger}$ University College London (UCL), Institute for Sustainable Heritage, The Bartlett, UCL Faculty of the Built Environment, Central House, 14 Upper Woburn Place, WC1H 0NN, London, UK.

${ }^{\S}$ Bournemouth University, Department of Accounting, Finance and Economics, Executive Business Centre, 89 Holdenhurst Road, BH8 8EB, Bournemouth, UK.

${ }^{\mathbb{T}}$ Bournemouth University, Department of Accounting, Finance and Economics, Executive Business Centre, 89 Holdenhurst Road, BH8 8EB, Bournemouth, UK.
} 
economy-tourism relationship. Consequently, the aim of this paper is to examine the dynamic links between tourism and economic growth in 98 countries, classified according to the quality of their political institutions, over the period 1995-2011, using a panel Vector Autoregressive (VAR) approach.

The quality of the political institutions is approximated based on the scores provided by the Polity IV index (www.systemicpeace.org/polity/polity4.htm). Countries are classified as democratic and non-democratic (see Table 1). Non-democratic classification denotes authoritarian or hybrid regimes (i.e. a mix of anocratic and autocratic regimes), whereas democratic classification includes the democratic and full democratic political systems.

\section{[Insert Table 1 around here]}

Furthermore, tourism income (proxied, for robustness purposes, by per capita international tourism receipts, ITRCPT, per capita tourism expenditures, ITEXP, and per capita tourist arrivals, IT ARR) and per capita real GDP (in $2005 \mathrm{US} \$, G D P P C$ ) are obtained from the World Development Indicators database. The data sample is purely dictated by data availability.

Clearly, the relationship between tourism and economic growth is a process that takes place over time, thereby necessitating a dynamic rather static framework. Therefore studies focusing on the steady-state or long-run relationship between the two variables can mostly provide a partial understanding of this complex relationship. In contrast, our dynamic analysis allows for capturing the adjustment in tourism and economic growth transpiring over time.

In particular, the output of the panel VAR model enables us to construct panel impulse response functions that illustrate the time path of tourism (economic growth) following a shock to economic growth (tourism). We therefore can observe the whole dynamic process from the initial shock to the long-run steady-state of the series of interest.

The panel VAR methodology combines the traditional VAR approach, which treats all the variables in the system as endogenous. Further, the panel-data approach allows for detecting any unobserved individual heterogeneity. In its general form, our model is the following:

$$
\Delta \ln Y_{i t}=A_{0}+A_{1} \Delta \ln Y_{i t-1}+A_{2} \Delta \ln Y_{i t-2}+\ldots+A_{j} \Delta \ln Y_{i t-j}+B X_{i t}+\mu_{i}+\lambda_{t}+\varepsilon_{i t}
$$

where $Y_{i t}$ is a vector of our key variables: ITRCPT and GDPPC. We apply the Panel VAR on the first difference $(\Delta)$ of the natural logarithm $(\ln )$ of the series instead of on the level series of the aforementioned endogenous variables, as according to Table 2, the former series are station- 
ary, while the latter are not. The autoregressive structure of model (1) allows all endogenous variables to enter the model with a number of $j$ lags. The number of lags is determined with the use of the Akaike Information Criterion. $X_{i t}$ is a vector of the exogenous variables, which are used as control variables, comprising: (i) labour force participation rate, capturing labour input, (ii) gross fixed capital formation as a \% of GDP, measuring capital input, and (iii) imports plus exports over GDP, capturing the degree of trade openness. The data for the exogenous variables come also from the World Development Indicators database. $\mu_{i}$ and $\lambda_{t}$ denote country fixed-effects and time fixed-effects, respectively, and $\varepsilon_{i t}$ is the error term.

\section{[Insert Table 2 around here]}

Descriptive statistics of the endogenous variables (both in levels and in their growth rates) are presented in Table 3 .

\section{[Insert Table 3 around here]}

We begin our panel VAR analysis with the full sample results illustrated in Figure 1. Our analysis is based on international tourism receipts as a proxy for tourism growth (as the results based on other proxies are qualitatively similar and available upon request).

\section{[Insert Figure 1 around here]}

We observe that, although there is a bidirectional relationship between tourism and economic growth in the short-run (i.e. during the first four years), in the long-run this turns into an economy-driven. Nevertheless, the consideration of the full sample can only lead us to draw some tentative conclusions, as the special qualities of our sample countries remain unmasked. Therefore, we need to observe the panel VAR results of countries classified by their level of democracy, as shown in Figure 2. As aforementioned, we have two classifications reflecting the different levels of political regimes.

\section{[Insert Figure 2 around here]}

As shown in Figure 2, an Economic-Driven Tourism Growth relationship is witnessed in countries with authoritarian or hybrid regimes (Non-democratic countries). The interpretation of such finding is twofold; first, it can be argued that in many instances authoritarian practices create a turbulent environment for economic activities and hence, for all economic sectors 
including tourism (Fletcher and Morakabati, 2008). This incurs in non-democratic regimes as governments often employ a rent-seeking behaviour to gain political support rather than providing public goods (Plümper and Martin, 2003).

Second, it has been established by the political economy literature that it is common for economies which lack democracy to be controlled by a single individual or a small group of individuals. Such power imbalances hinder the economy to grow or spread the benefits of economic activity across society due to corruption (de Vaal and Ebben, 2011; Drury et al., 2006; Mo, 2001). Thus, we maintain that the way that the economy is controlled in nondemocratic states influences tourism growth negatively.

In contrast, countries with democracy or full democracy exhibit a bidirectional relationship. It is suggested that countries with democratic regimes are able to exploit the maximum capacity of their economies and consequently, are at a good position to support investment in their various sectors. Moreover, given that the benefits from each sector can be shared more fairly across society it is reasonable to argue that sectoral performance (in our case, tourism) could assist economic growth.

In short, these results highlight the importance of panel country investigation of the tourismeconomy relationship based on criteria that move away from geographic and economic characteristics.

An interesting avenue for further research is to examine whether the tourism-growth nexus is sensitive to alternative country groupings based on the level of government effectiveness, tourism specialisation, or the degree of tourism competitiveness.

\section{References}

Acemoglu, D., Johnson, S., Robinson, J. A., Yared, P., 2008. Income and democracy. The American Economic Review, 808-842.

Antonakakis, N., Dragouni, M., Filis, G., 2015. Tourism and growth: The times they are achanging. Annals of Tourism Research 50, 165-169.

Chang, C.-L., Khamkaew, T., McAleer, M., 2012. IV estimation of a panel threshold model of tourism specialization and economic development. Tourism Economics 18 (1), 5-41.

Chatziantoniou, I., Filis, G., Eeckels, B., Apostolakis, A., 2013. Oil prices, tourism income and economic growth: A structural VAR approach for European Mediterranean countries. Tourism Management 36, 331-341. 
de Vaal, A., Ebben, W., 2011. Institutions and the relation between corruption and economic growth. Review of Development Economics 15 (1), 108-123.

Dritsakis, N., 2012. Tourism development and economic growth in seven mediterranean countries: A panel data approach. Tourism Economics 18 (4), 801-816.

Drury, A. C., Krieckhaus, J., Lusztig, M., 2006. Corruption, democracy, and economic growth. International Political Science Review 27 (2), 121-136.

Fletcher, J., Morakabati, Y., 2008. Tourism activity, terrorism and political instability within the commonwealth: The cases of Fiji and Kenya. International Journal of Tourism Research $10(6), 537-556$.

Im, K. S., Pesaran, M. H., Shin, Y., 2003. Testing for unit roots in heterogeneous panels. Journal of Econometrics 115 (1), 53-74.

Ivanov, S., Webster, C., 2013. Tourism's impact on growth: The role of globalisation. Annals of Tourism Research 41, 231-236.

Levin, A., Lin, C.-F., James Chu, C.-S., 2002. Unit root tests in panel data: Asymptotic and finite-sample properties. Journal of Econometrics 108 (1), 1-24.

Mehlum, H., Moene, K., Torvik, R., 2006. Institutions and the resource curse*. The Economic Journal 116 (508), 1-20.

Mo, P. H., 2001. Corruption and economic growth. Journal of Comparative Economics 29 (1), $66-79$.

Plümper, T., Martin, C. W., 2003. Democracy, government spending, and economic growth: A political-economic explanation of the Barro-effect. Public Choice 117 (1-2), 27-50.

Rodriguez, F., Sachs, J. D., 1999. Why do resource-abundant economies grow more slowly? Journal of Economic Growth 4 (3), 277-303.

Schubert, S. F., Brida, J. G., Risso, W. A., 2011. The impacts of international tourism demand on economic growth of small economies dependent on tourism. Tourism Management 32 (2), 377-385.

Seetanah, B., 2011. Assessing the dynamic economic impact of tourism for island economies. Annals of Tourism Research 38 (1), 291-308. 
Figure 1: Impulse responses based on the full sample estimation for the period 1995-2011 Accumulated Response of GDPPCGR to ITRCPTGR Accumulated Response of ITRCPTGR to GDPPCGR


Note: GDPPCGR and ITRCPTGR denote per capita real GDP growth and per capita international tourism receipts growth, respectively. 
Figure 2: Impulse responses for the political regime classifications estimation for the period 1995-2011

Accumulated Response of GDPPCGR to ITRCPTGR

Accumulated Response of ITRCPTGR to GDPPCGR
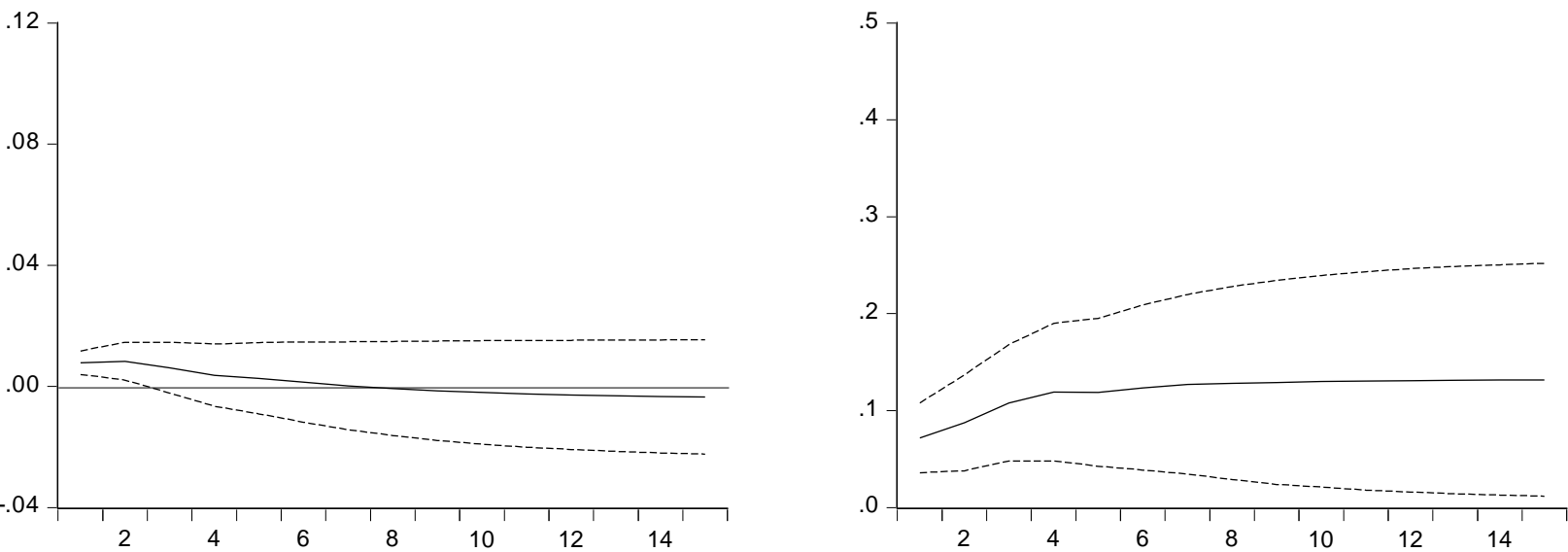

Accumulated Response of GDPPCGR to ITRCPTGR

Accumulated Response of ITRCPTGR to GDPPCGR
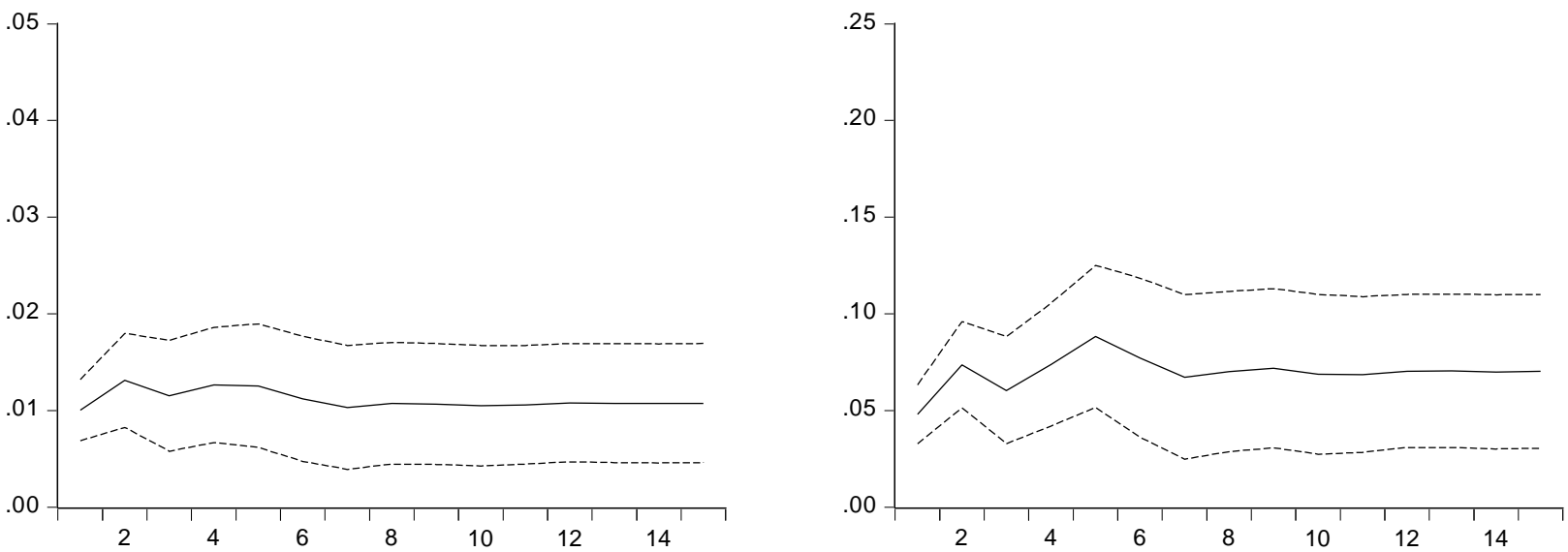

Accumulated Response of GDPPCGR to ITRCPTGR

Accumulated Response of ITRCPTGR to GDPPCGR
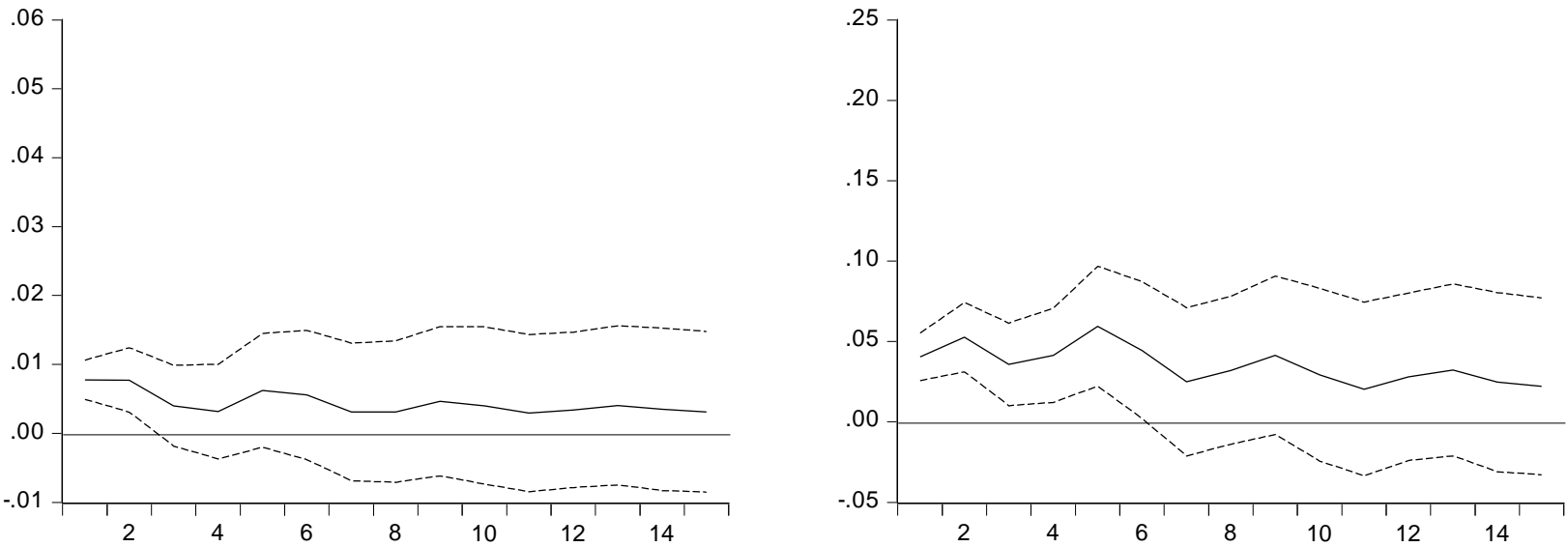

Note: Impulse responses for Non-democratic and Democratic classifications are shown in the top and lower panels, respectively. GDPPCGR and ITRCPTGR denote per capita real GDP growth and per capita international tourism receipts growth, respectively. 
Table 1: Democratic and Non-democratic countries

\begin{tabular}{|c|c|c|c|}
\hline Democratic Countries & Acronym & Non-democratic Countries & Acronym \\
\hline Albania & ALB & Algeria & DZA \\
\hline Australia & AUS & Angola & AGO \\
\hline Ausria & AUT & Armenia & ARM \\
\hline Belgium & BEL & Azerbaijan & AZE \\
\hline Bolivia & $\mathrm{BOL}$ & Bahrain & $\mathrm{BHR}$ \\
\hline Brazil & BRA & Bangladesh & $\mathrm{BGD}$ \\
\hline Bulgaria & BGR & Belarus & BLR \\
\hline Canada & $\mathrm{CAD}$ & Burundi & $\mathrm{BDI}$ \\
\hline Cape Verde & $\mathrm{CPV}$ & Cambodia & KHM \\
\hline Chile & $\mathrm{CHL}$ & China & $\mathrm{CHN}$ \\
\hline Colombia & $\mathrm{COL}$ & Croatia & HRV \\
\hline Costa Rica & CRI & Egypt, Arab Rep. & EGY \\
\hline Cyprus & CYP & Ethiopia & ETH \\
\hline Czech Republic & $\mathrm{CZE}$ & Ghana & GHA \\
\hline Denmark & DNK & Indonesia & IDN \\
\hline Dominican Republic & DOM & Jordan & JOR \\
\hline Equador & $\mathrm{ECU}$ & Kazakhstan & KAZ \\
\hline El Salvador & SLV & Kenya & KEN \\
\hline Estonia & $\mathrm{EST}$ & Kyrgyz Republic & KGZ \\
\hline Finland & FIN & Lao PDR & $\mathrm{LAO}$ \\
\hline France & FRA & Malaysia & MYS \\
\hline Germany & GER & Morocco & MAR \\
\hline Greece & GRE & Nepal & NPL \\
\hline Guatemala & GTM & Pakistan & PAK \\
\hline Honduras & HND & Russian Federation & RUS \\
\hline Hungary & HUN & Sierra Leone & SLE \\
\hline India & IND & Singapore & SGP \\
\hline Israel & ISR & Sri Lanka & LKA \\
\hline Italy & ITA & Sudan & SDN \\
\hline Japan & JPN & Tanzania & TZA \\
\hline Korea, Republic & KOR & Tunisia & TUN \\
\hline Latvia & LVA & Yemen, Rep. & YEM \\
\hline Lesotho & LSO & & \\
\hline Lithuania & LTU & & \\
\hline Macedonia, FYR & MKD & & \\
\hline Malawi & MWI & & \\
\hline Mali & MLI & & \\
\hline Mauritius & MUS & & \\
\hline Mexico & MEX & & \\
\hline Moldova & MDA & & \\
\hline Mongolia & MNG & & \\
\hline Namibia & NAM & & \\
\hline Netherlands & NLD & & \\
\hline New Zealand & NZL & & \\
\hline Nicaragua & NIC & & \\
\hline Norway & NOR & & \\
\hline Panama & PAN & & \\
\hline Paraguay & PRY & & \\
\hline Peru & PER & & \\
\hline Philippines & PHL & & \\
\hline Poland & $\mathrm{POL}$ & & \\
\hline Portugal & PRT & & \\
\hline Romania & $\mathrm{ROM}$ & & \\
\hline Slovak Republic & SVK & & \\
\hline Slovenia & SVN & & \\
\hline South Africa & $\mathrm{ZAF}$ & & \\
\hline Spain & ESP & & \\
\hline Sweden & SWE & & \\
\hline Switzerland & $\mathrm{CHE}$ & & \\
\hline Thailand & THA & & \\
\hline Turkey & TUR & & \\
\hline Ukraine & UKR & & \\
\hline United Kingdom & GBR & & \\
\hline United States & USA & & \\
\hline Uruguay & URY & & \\
\hline Venezuela, RB & VEN & & \\
\hline
\end{tabular}

(www.systemicpeace.org/polity/polity4.htm.. Democratic countries have a score between 6 and 10, whereas Non-democratic countries have a score between -10 and 5 . 
Table 2: Panel unit root test results

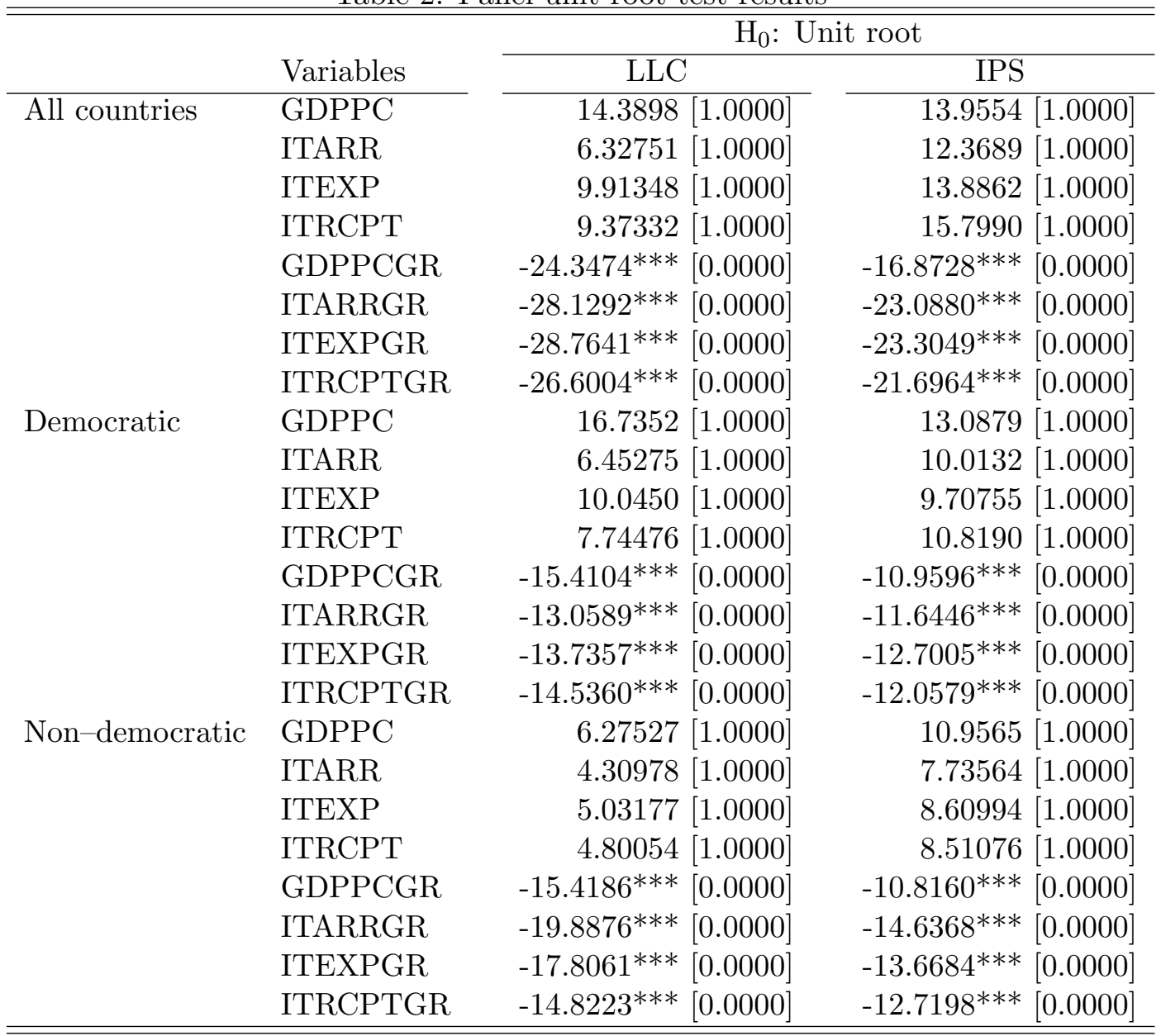

The numbers in brackets denote $p$-values. The LLC and IPS tests are the panel unit root test of Levin et al. (2002) and Im et al. (2003), respectively, performed using the Newey-West bandwidth selection with Barlett Kernel, and the Schwartz Bayesian Criterion is used to determine to optimal lag length. ${ }^{*},{ }^{* *}$ and ${ }^{* * *}$ indicate rejection of the null hypothesis at the 10,5 and 1 percent levels of significance, respectively. 
Table 3: Descriptive Statistics - Full sample \& by political regime

\begin{tabular}{|c|c|c|c|c|c|c|c|c|}
\hline & \multicolumn{8}{|c|}{ All (98) countries } \\
\hline & Mean & Maximum & Minimum & Std. Dev. & Skewness & Kurtosis & JB & Obs. \\
\hline GDPPC & 11494.08 & 87716.7 & 125.267 & 15058.36 & 1.805935 & 6.176781 & $1851.967^{*}$ & 1921 \\
\hline ITARR & 0.899331 & 103.5508 & 0.001305 & 2.757344 & 917 & 1004.059 & $80454658^{*}$ & 1921 \\
\hline ITEXP & 57.565 & 1298055 & 0.931889 & 29622.63 & & 1914.489 & $2.93 \mathrm{E}+08^{*}$ & 1921 \\
\hline ITRCP] & 0.1 & 3106 & 532 & 3.892 & & 1789 & $2.56 \mathrm{E}+08^{*}$ & 1921 \\
\hline GR & 26 & 0.32 & .192922 & 0.039761 & -0.0 & 8.59 & $2362.244^{*}$ & 1808 \\
\hline GR & -0.027283 & 1.28 & -3.187505 & 0.228891 & 93 & 50.4 & 17460 & 1808 \\
\hline & 0.01051 & 2.391994 & -4.056758 & 0.275857 & 721 & 40.66897 & $107924.2^{*}$ & 1808 \\
\hline \multirow[t]{2}{*}{ ITRCPTGR } & -0.00 & 3.48 & -3.693053 & 7256 & -0.9 & & 99835 & 1808 \\
\hline & \multicolumn{8}{|c|}{ Democratic (66) countries } \\
\hline & Mean & Maximum & Minimum & Std. Dev. & Skewness & Kur & JB & Obs. \\
\hline GDPPC & 2914 & & & & & & 5354.08 & 544 \\
\hline & 0 & 10 & & & & & 3668 & 44 \\
\hline & 2 & 12 & & .98 & & 184 & 66206 & 44 \\
\hline ITR & 10. & .3 & & .07 & & & 5565 & 544 \\
\hline GDPPCGR & 03672 & 0.322496 & 5308 & 006 & & & $1113.6^{*}$ & 512 \\
\hline סת מח ח & -0040458 & & & & & & $20247.7^{*}$ & 512 \\
\hline & & & & & & & $1 *$ & 512 \\
\hline \multirow[t]{3}{*}{ ITRCPTGR } & 2 & 44 & 3.693053 & 0.420858 & -0.606085 & 05 & 11633.39 & 312 \\
\hline & \multicolumn{8}{|c|}{ Non-democratic $(32)$ countries } \\
\hline & $\mathrm{Mez}$ & Nida & Minimum & Std. Dev. & Skewness & Kurtosis & JБ & Obs. \\
\hline GD & 5627.282 & 37582.7 & 203.053 & 7428.607 & 2.834821 & 10.96911 & $2642.375^{*}$ & 663 \\
\hline ITARR & 0.446066 & 21.86591 & 0.001305 & 1.203505 & 11.69013 & 177.1885 & $853288.5^{*}$ & 663 \\
\hline ITEXP & 195.5019 & 4556.744 & 0.931889 & 356.0236 & & 47.07758 & $56950.71 *$ & 663 \\
\hline & 266.3676 & & & & & & $154806.6^{*}$ & 663 \\
\hline GDI & 0.027245 & & -0.192922 & 107 & & 6.5 & $419.4704^{*}$ & 624 \\
\hline & & & -2.289284 & & & & $18774.69^{*}$ & 624 \\
\hline ITE & -0.000734 & 2.391 & -2.23065 & 0.266079 & 1.106608 & 29.7708 & 18760.93* & 624 \\
\hline ITRCPTGR & -0.00225 & 1.704141 & -2.398752 & 0.257225 & -1.232902 & 20.37821 & $8010.138^{*}$ & 624 \\
\hline
\end{tabular}

GDPPC, ITARR, ITEXP and ITRCPT, denote per capita per capita real GDP (in 2005 US\$), per capita tourist arrivals, per capita tourism expenditures, and per capita international tourism receipts, respectively, and GDPPCGR, IT ARRGR, ITEXPGR and ITRCPTGR are the aforementioned series' growth rates (i.e. first difference of natural logarithm). JB denote Jarque-Bera. * indicates 1 percent level of significance. 